Studia z Filologii Polskiej

i Słowiańskiej, 46

SOW, Warszawa 2011

\author{
Beata Raszewska-Żurek
}

\title{
Kobieca cnota. \\ Próba zrozumienia ewolucji znaczenia cnoty na przestrzeni wieków
}

Współczesny użytkownik języka polskiego zapytany o to, czym jest cno$t a$, co znaczy to słowo, najprawdopodobniej w pierwszym skojarzeniu odniesie się do dziewictwa, czystości seksualnej. Takie rozumienie obecne jest w dzisiejszym języku potocznym. W przestrzeni publicznej ze słowem cnota spotykamy się rzadko, nosi ono już cechy archaizmu, a jeśli się pojawia, to także raczej w znaczeniu 'dziewictwo'. O współczesnym rozumieniu Puzynina pisze: „Pojęcie cnoty jest w ogólnym języku polskim zdeprecjonowane, chyba poprzez dominację znaczenia cnoty dziewictwa i związek z moralnością małomieszczańską" (Puzynina 1992, 159, przypis 18). Zwraca ona uwagę nie tylko na dominację znaczenia 'dziewictwo', ale i na wynikające $\mathrm{z}$ tego, charakterystyczne dla języka polskiego obniżenie wartości pojęcia cnota, podczas gdy w światowej literaturze aksjologicznej jest ono stawiane wysoko.

W Słowniku polskich leksemów potocznych cnota występuje w znaczeniu 1. 'błona dziewicza', 2. 'dziewica', 3. 'przesadnie cnotliwa lub świętoszkowata kobieta' (SPLP), zatem cnota - czystość, dziewiczość przeniesiona została w potocznych użyciach na anatomiczny dowód tejże i na kobietę, która dziewictwem się charakteryzuje, ale też na kobietę o pewnym rodzaju moralności i tu już z odcieniem negatywnego, ironicznego nacechowania. W Słowniku potocznej polszczyzny cnota w ogóle nie oznacza pojęcia, wy- 
stępuje tylko jako określenie kobiety - cnota mówi się po pierwsze 'o dziewczynie przesadnie skromnej, spokojnej, grzecznej, dobrze wychowanej', np. To jest dopiero cnota! Nietykalna, księżniczka $z$ wieży ciśnień i - po drugie 'o dziewicy', np. Nie była ona cnota, nie da się zaprzeczyć, robiłem z nia przez noc różne dziwne rzeczy (SPP).

Współczesne słowniki ogólne języka polskiego przedstawiają cnotę nieco inaczej. U Doroszewskiego pierwsze znaczenie to 'przestrzeganie zasad etyki; zespół dodatnich cech moralnych, prawość, szlachetność, zacność, drugie (zwykle w l. mn.) - 'dodatnie cechy, rysy charakteru, przymioty, zalety' i dopiero trzecie - 'dziewiczość, niewinność, czystość' (SJPDor), identycznie jest u Szymczaka. Dunaj pod hasłem cnota zamieszcza dwa znaczenia: 1. 'zespół wysokich wartości moralnych; prawość, zacność, 2. 'dziewictwo, dziewiczość' (SJPDun). Praktyczny słownik współczesnej polszczyzny podaje znaczenie 'dziewictwo, dziewiczość, niewinność także jako trzecie (PSWP), tu jednak pośród synonimów znajdujemy określenia hymen i błona dziewicza - czyli nawiązanie do języka potocznego - cnota odnosi się nie tylko do abstrakcyjnego pojęcia, ale też ulega konkretyzacji w jego biologiczny przejaw. O ile w definicjach żadnego ze współczesnych słowników ogólnych nie określono, że cnota w takim rozumieniu odnosi się tylko do kobiet, o tyle skonkretyzowane znaczenia, a również cytowane połączenia, jak np. panieńska, dziewczęca cnota (PWSP); panieńska cnota (SJPSzym); panna trwająca $w$ cnocie (SJPDun); dybać, nastawać na cnotę panny, dziewczęcia (PWSP), wyraźnie o tym świadczą. Nigdzie w słownikach współczesnych nie ma żadnych śladów, które wskazywałyby, że cnota jako czystość seksualna dotyczy mężczyzny.

W definicjach słowników współczesnego języka polskiego zachowane jest tradycyjne, szerokie znaczenie cnoty. Odnosi się ono do silnie nacechowanej pozytywnie wartości z kategorii wartości moralnych, stanowiącej pewnego rodzaju uogólnienie, obejmujące nazwy różnych innych wartości. W takim szerokim i mało precyzyjnym znaczeniu cnota obecna była w języku polskim przez wieki, już od staropolszczyzny, gdzie oznaczała po pierwsze 'zacność, cnotliwość' i po drugie 'jakąś zaletę etyczną' (Sstp). Wydaje się, że współcześni użytkownicy języka polskiego, choć mają wyraz cnota w zasobie słownictwa, jednak już go nie używają, a jeżeli, to w znaczeniu 'dziewictwo' albo 'dziewica'. Przyczyną tego może być właśnie bardzo szeroki zakres leksemu cnota w rozumieniu 'zespół cech moralnych'. Nie określa on precyzyjnie, których konkretnie cech dotyczy, a $\mathrm{z}$ tego powodu jest niezbyt wygodny w codziennym użytku. Nie wyjaśnia to jednak, dlaczego, spośród wielu wartości moralnych, wyrażanych przez wieki wyrazem cnota, akurat 'czystość seksualna' przetrwała jako żywe i wciąż używane znaczenie. 
Cnota jako pojęcie ogólne wiązała się $\mathrm{z}$ funkcjonowaniem człowieka w społeczności, w przestrzeni publicznej, co powodowało, że w inny sposób odnosiła się do mężczyzny, a w inny do kobiety. Pośród precyzyjniejszych pojęć - składników cnoty, jak roztropność, umiar, dzielność, godność, mądrość, zacność, sprawiedliwość i inne, większość dotyczyła mężczyzn. Wiele cnót, np. obywatelskie czy rycerskie, miało związek z uczestnictwem w życiu społecznym i politycznym, a to było przez wieki domeną mężczyzn, którzy w patriarchalnym społeczeństwie odmawiali kobietom takiego prawa lub przynajmniej silnie je ograniczali. $Z$ tej różnicy w pozycji mężczyzny i kobiety wynika fakt, że cnota zawiera odmienny katalog wartości szczegółowych dla kobiety niż dla mężczyzny. Warto zatem prześledzić, w jaki sposób leksem cnota łączył się z kobietą na przestrzeni wieków. Być może pozwoli to na jakieś, częściowe przynajmniej, wyjaśnienie dość zaskakującego rozwoju semantycznego - od ogólnego pojęcia etycznego do błony dziewiczej.

Cytowana już definicja cnoty w staropolszczyźnie jest bardzo ogólna. Nie ma w niej znaczenia 'czystość seksualna' ani żadnego odniesienia do kobiet czy płci w ogóle. Staropolska cnota dotyczy najczęściej religijnej sfery życia człowieka i nawiązuje silnie do chrześcijańskiego rodowodu tego pojęcia ${ }^{1}$, a także do sfery moralności i obyczajowości, czyli do zasad funkcjonowania jednostki w społeczeństwie. Cnota pojawia się najczęściej jako pojęcie samo w sobie, pozbawione odniesień do osób. Ale występuje też jako cecha człowieka w kontekście społecznym, co w staropolszczyźnie oznacza w istocie cechę mężczyzny, z racji ograniczonego uczestnictwa kobiet w życiu społecznym. Mimo to w kontekstach przytaczanych w Słowniku staropolskim pojawiają się takie, w których cnota występuje w połączeniu z kobietą. Stanowią one wcale niemałą część, zarówno w samym haśle cnota, jak i w powiązanych z nim przymiotnikach ${ }^{2}$.

${ }^{1}$ Pojęcie cnota wywodzi się z filozofii Platona, autora teorii czterech cnót podstawowych. Zgodnie z pitagorejską koncepcją cnoty jako ładu i harmonii duszy, Platon uważał, że każda jej część musi mieć udział w tej harmonii, więc każda musi mieć swoją cnotę. Wyróżniał trzy części duszy - rozumną, którą rządzi mądrość, impulsywną, rządzoną przez męstwo i pożądliwą - przez umiarkowanie, a czwarta cnota - sprawiedliwość łączy wszystkie części duszy i utrzymuje wśród nich ład, aby każda spełniała swoją funkcję (Tatarkiewicz, 1931 [1978], 98). Z pewnymi różnicami termin ten został przejęty przez tradycję chrześcijańską, w której głęboko się zakorzenił. Wg Słownika teologii biblijnej cnota polega na życiowym stosunku do Boga, na zgodności z jego słowami i na posłuszeństwie jego woli (Léon-Dufour 1985).

${ }^{2} \mathrm{~W}$ niniejszym opracowaniu uwzględniam powiązane słowotwórczo z cnota przymiotniki oraz antonimy, ponieważ analiza kontekstów samej cnoty nie daje wystarczająco jasnego obrazu jej połączenia z kobietą, a tym samym nie rzuciłaby światła na współczesną zmianę znaczenia. 
Łączenie cnoty z kobietą odbywa się w staropolszczyźnie przede wszystkim na gruncie religijnym. Wynika to w dużym stopniu $\mathrm{z}$ sakralnego charakteru znacznej części ówczesnego piśmiennictwa, jak i ze średniowiecznego kultu świętych propagującego ich jako wzorce osobowe. Większość zapisów cnoty związanej z kobietą właśnie świętych dotyczy i, jakkolwiek definicja słownikowa tego nie precyzuje, wydaje się, że w tych kontekstach cnota oznacza jednak czystość seksualną, choć niekoniecznie do niej tylko się ogranicza. O takim rozumieniu świadczyć mogą połączenia szeregowe cna i czysta - to odnosi się do św. Doroty z Cezarei, dziewicy i męczennicy: Dorothea, czna dzewko czysta ... czebe czy (leg. czci) cirkew swąta (Sstp) 'Doroto, cna dziewko czysta, ciebie czci cerkiew święta’3 i cna dziewica: Czsney dzieuicze (1444 r., Sstp). Ani przymiotnik czysty, ani rzeczownik dziewica nie rozstrzygają jednoznacznie na poziomie definicji, że chodzi o czystość seksualną, ale wynika to w znacznym stopniu z kontekstów, w jakich występują. Dziewica w staropolszczyźnie to 'dziewczyna, panna, kobieta niezamężna, dziewica, virgo, puella', 'córka, dziecko', dziewictwo zaś - 'panieństwo, wiek panieński, stan panieński, dziewictwo, virginitas' (Sstp). Zatem definicyjnie dziewica może oznaczać po prostu kobietę niezamężną, niekoniecznie taką, która nigdy nie uprawiała seksu, jak we współczesnym rozumieniu. Jednak w cytowanym materiale znajdują się odniesienia do świętych dziewic, dziewic czystych, w tym do Matki Bożej i św. Katarzyny, oraz epitety nawiązujące do czystości seksualnej, np. [...] onø dzeuiczø vsrzy cysthø; dzyevycztwo nye porvsone, [...] ya chovacz slyubyla moye dzyevycztwo (Sstp) 'onę dziewicę ujrzy czystą; dziewictwo nie poruszone, [...] ja chować ślubiła moje dziewictwo'. Ponadto w realiach piętnastowiecznych seks bez małżeństwa nie był zwyczajowo dopuszczany, więc $\mathrm{w}$ praktyce niemężatka oznacza dziewicę4.

Czysty znaczy po pierwsze 'czysty fizycznie, niebrudny', a po drugie 'bez zmazy moralnej (lub rytualnej)', tutaj, pośród innych, figuruje zapis o Matce Bożej: Maria, czista dzewicze, [...] cista Crista gesz poczøla (XV w., Sstp) 'czysta, Chrysta poczęła', w którym odniesienie do czystości seksualnej nie budzi wątpliwości. Postać Matki Bożej przywołana jest także jako wzorzec w kontekście cności: Maya panny vczyeszenye, $k v$ szvey cznosczy obronyenye $z$ Maryey zywvotha (1453 r., Sstp) 'Mają panny ucieszenie, ku swej cności obronienie z Maryi żywota'. Warto zwrócić uwagę na „obronienie cności” - pokazano

${ }^{3} \mathrm{Z}$ powodu trudności, jakich nastręcza staropolska grafia, podaję też uproszczone, uwspółcześnione odczytanie niektórych zapisów, mające służyć jedynie oddaniu ich sensu.

${ }^{4}$ Wydaje się, że o tym mówi zapis: taakesz malzenstwo rodzy dzewycze, a teesz malzenstwo skazy dzewicze (Sstp). 
tu cnotę (cność), czyli dziewictwo kobiety, jako wartość, której trzeba bronić, a więc wartość w stanie zagrożenia - ten element widoczny jest wyraźnie w obrazie cnoty kobiecej w późniejszych wiekach.

W staropolszczyźnie przymiotnik cny w połączeniu z kobietą nie zawsze dotyczy dziewictwa. Na pewno nie ma takiego znaczenia w zapisach, w których mowa o cnych niewiastach, tu w znaczeniu 'nieposzlakowanych, mających dobrą opinię?: Szwyadeczstwo gynych dobrych cznych nyewyasth, [...] $z$ oszmya gynych dobrych cznymy nyewyasthamy, ysz to dzyecza bylo zywo (Sstp) 'Świadectwo jinych dobrych, cnych niewiast, (...) z ośmia jinych dobrych cnymi niewiastami, iż to dziecię było żywe’, gdyż świadectwo przed sądem dawały raczej stateczne mężatki, panny w hierarchii społecznej znajdowały się niżej i rzadziej występowały w takiej roli ${ }^{5}$.

Od początków języka polskiego widać pewne powiązanie cnoty z płcią żeńską, w najstarszych kontekstach daje się zauważyć, że przynajmniej w części opiera się ona na rozumieniu cnoty jako czystości seksualnej. Wynika to oczywiście z uznawania dziewictwa w kulturze chrześcijańskiej za bardzo istotną wartość, z jednej strony zasługującą na podziw, z drugiej zaś będącą absolutnym wymogiem. Wywodzi się on z dekalogu i przykazania „nie cudzołóż”, gdzie nie jest ograniczony do jednej płci, jednak w praktyce o wiele surowiej był egzekwowany od kobiet. W ich przypadku zachowanie dziewictwa do ślubu uważane było przez wieki za konieczny warunek zamążpójścia. Ale cnota dotycząca kobiet nie ogranicza się do samego dziewictwa zachowanego do ślubu, łączy się także z wymogiem zachowania wierności małżeńskiej, niekoniecznie stosowanym do obojga małżonków. M. Bogucka (1998, 5354) pisze, że „wierność w staropolskim kodeksie obyczajowym obowiązywała bezwzględnie kobietę (surowość ta wynikała $\mathrm{z}$ chęci zabezpieczenia prawego pochodzenia potomstwa), dla mężczyzn obyczaj był bardziej wyrozumiały. W Polsce nie doszło do penalizacji prostytucji [...]. Wszystkie zjazdy szlachty włącznie z sejmami były obsługiwane przez kobiety uprawiające płatną miłość i szlachta korzystała $z$ tej formy »rozrywki« z dużą swobodą". Stan taki wpi-

${ }^{5}$ Słownik staropolski podaje też przykład stosowania przymiotnika cny jako formy grzecznościowej: Jan polyeczyl opyekanye szwego gymyenya wszythkego po szwey szmyerczy czney Doroczye, szwey zenye. Wydaje się, że w poprzednich zapisach pochodzących z ortyli przymiotnik cny może pełnić tę samą funkcję i częściowo może być pozbawiony znaczenia, gdyż w zapisach piętnastowiecznych powszechnie używano grzecznościowych określeń przed nazwami osobowymi, wskazywały one na przynależność społeczną osoby. Dla mieszczaństwa zarezerwowany był przymiotnik cny, tyle że częściej pojawiał się po łacinie - honestus (więcej na temat określeń stosowanych dla różnych grup społecznych por. Ras zewska-Żu rek 2006, 24-26). 
suje się w ogólną sytuację kobiet w społeczeństwach patriarchalnych, w ich niższą w stosunku do mężczyzn pozycję utrzymującą się przez wieki. „Obowiązkiem każdego członka była dbałość o honor rodziny. Plamiło ten honor tchórzostwo mężczyzny, a przede wszystkim naganne zachowanie kobiety, stąd silna kontrola rodziny nad należącymi do niej kobietami” - stwierdza Bogucka $(2005,75)$.

Słownik polszczyzny XVI w. podaje o wiele bogatszą niż w staropolszczyźnie definicję cnoty. Zawiera się w niej rozumienie ogólne - cnota to 'zacność, prawość, szlachetność, dodatnie cechy moralne', często występuje ono w kontekstach z nazwami poszczególnych cnót, jak dowcip, dzielność, mądrość, poczciwość, sprawiedliwość, zacność. Wyróżnione tutaj zostały cnoty chrześcijańskie, przymioty przypisywane Bogu, talent i zdolności artystyczne i wreszcie - niewinność, czystość. W tym ostatnim rozumieniu cnota najczęściej odnosi się do kobiet. Spotykamy tu wyrażenia: cnota czystości (panieńskiej), cnota panieńska; cnoty bronić, przestrzegać; cnote stracić, zruszyć, zachować.

Słownik nie zawsze umieszcza konteksty dotyczące kobiet w wydzielonej części hasła o znaczeniu 'czystość, nie zawsze też cnota kobiet tylko do tego aspektu się ogranicza. Nie sposób nie zauważyć zapisu przyznającego kobiecie w XVI w. pozycję równą mężczyźnie: [białegłowy] naydziejz / ktore oycom fwym / ábo bráciej / ábo mężom / w cnothách / á w godności rowne fa (SXVI). Charakterystyczne połączenie z godnością świadczy o tym, iż przypisana tu kobiecie cnota rozumiana jest na pewno znacznie szerzej niż czystość w sensie seksualnym. Biorąc pod uwagę społeczne realia tego okresu, trzeba zaznaczyć, że przyznanie kobietom prawa dysponowania cnotą (w szerokim rozumieniu) w tym samym stopniu co mężczyznom jest wyjątkowe i Łukasz Górnicki znacznie odbiega w tym stwierdzeniu od poglądu ogółu.

Większość poświadczeń szesnastowiecznych traktuje o cnocie jako pojęciu abstrakcyjnym, nie odwołując się do jej nosicieli, zatem bez ograniczenia do którejkolwiek z płci. W innych leksem cnota odnosi się ogólnie do człowieka - w zapisach pojawiają się określenia ktokolwiek, wszyscy, każdy lub człowiek, np. Bez cnoty cżłowyek źwirzę (SXVI). Kontekst ten może w równym

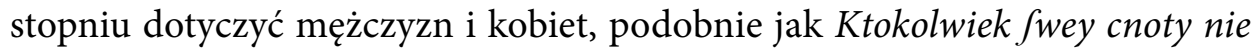
ma / Prozno fie sláchetnym mniema (SXVI). Cnota w XVI w. jako wartość odnosi się głównie do dwóch sfer bytu człowieka - religijnej i społeczno-obyczajowej. Podobnie jak w poprzednim okresie, związek z zasadami społeczno-obyczajowymi uzasadnia odmienne rozumienie cnoty u mężczyzn i kobiet ${ }^{6}$.

${ }^{6}$ B o gu cka $(1998,43)$ pisze: „wydaje się, że sytuacja kobiet była w Polsce lepsza w kręgach szlacheckich niż w środowiskach miejskich. W zasadzie kobiety traktowane były bez 
Katalog pojęć towarzyszących cnocie we wspólnych kontekstach, tam gdzie dotyczy ona bezpośrednio kobiet, jest jednak dość skromny. Poza wspomnianą wyżej godnością, jednorazowo związaną z „cnotą kobiecą”, powtarza się wstyd, srom i czystość. Pojedynczo wystąpiły też świętobliwość i pokora. Wydaje się, że te właśnie pojęcia budują ogólny obraz cnoty kobiety. Trzy pierwsze odnoszą się niewątpliwie do nietykalności seksualnej.

Pojęcia $\operatorname{srom}^{7}$ i wstyd są synonimiczne - srom 'wstyd, przykre uczucie wywołane świadomością złego postępowania, naganą albo lękiem przed naganą, przed znalezieniem się w nagannej sytuacji' (Sstp), wstyd 'wstydliwość, skłonność przyrodzona do wstydania się, sromięźliwość uczciwa' $(\mathrm{L})^{8}$. Czystość pośród innych, ma także znaczenie 'dziewiczość, niewinność, wstydliwość, skromność, nienaruszalność płciowa; całkowita wstrzemięźliwość płciowa; bezżenność' (SXVI). Wstydliwość, obecna we wszystkich trzech definicjach, w odniesieniu do kobiet dotyczy sfery seksualnej. Potwierdza to kontekst: Wthora cnota yeftći wftyd, á cżyftosć / dla cżego áby nyerzadna nye byłá / miłowáć tho káżda ma (SXVI). Warto zwrócić uwage, że zalecane, czy raczej, wnioskując $\mathrm{z}$ tonu tego komunikatu, wymagane jest od kobiety nie tylko zachowanie czystości, ale też jej umiłowanie i zaraz pojawia się groźba oskarżenia o „bycie nierządną” w razie braku tego umiłowania. Trzeba dodać, że nierząd (czyli rozpusta) w realiach społecznych XVI wieku to zarzut ciężkiego kalibru. Jego ówczesną ocenę oddaje dobitnie i obrazowo zapis: [...] cudzołożnica fię odłącżona od Chryftufá ftawfzy / dobrowotnieś [!] fię ále mizernie jpuśćiłá $z$ wyfokośći pánieńftwá cżyftego / w przepaść nierzadu fmrodliwego (SXVI). W ślad za taką oceną idzie wykluczenie z życia społecznego, czemu dają wyraz wielcy tej epoki - Rej i Kochanowski: to dziewka od matki za teftament bierze / Ze cnotliwa niebędzie fiedzieć przi wfzetecżney (SKoch); Gdy [biała głowa] ftraci w/tyd iuż ni rozum ani żadne ftowa Cżo fie ku cznocie fciagaja iuz iey nie Jmakuja (SXVI). Kobieta, która zrezygnuje z zachowania cnoty, nie może w żadnym wypadku liczyć na zrozumienie mężczyzn (w tym nawet sprawcy utraty cnoty): ktożby fnas ták był fzalony / ktoryby miał żonę / dzieći opuścić [...] á ku niecnotliwey niewieśćie przyftáć (SXVI). Widać w tym

względu na wiek, jako osoby niezdolne do samodzielności i skazane na asystencję opiekunów prawnych". Autorka przytacza jednak różne odstępstwa od tej zasady, np. występowanie przed sądem, co powoduje, że pozycja kobiet w życiu społecznym, jakkolwiek ogólnie niska i podległa względem mężczyzny, w niektórych przypadkach bywała nie aż tak zła.

${ }^{7}$ Słownik Lindego pod hasłem srom podaje zapis: Srom jest ona przedniq cnotą, która jest wszystkich cnot stróżem - wydaje się, że nie jest on ograniczony do kobiet, dotyczy chyba ludzi w ogóle.

${ }^{8} \mathrm{O}$ współczesnym obrazie pojęcia wstyd por. Jędrzejko 2000. 
szesnastowieczne spojrzenie na kobietę w ogóle - cnota, czyli czystość seksualna, jest najistotniejszym aspektem, który decyduje o jej wartości. Brak cnoty, niezależnie od innych zalet, może spowodować odmówienie jej prawa do normalnej społecznej egzystencji, bez szansy na rehabilitację. Utrata cnoty jest ostateczna, chociaż w kolejnym zapisie nie ma mowy o kobiecie, to wydaje się, że fraza 'stracić cnotę' dotyczy kobiety i znaczy 'stracić dziewictwo': Ano cżo ieft nagorfzego iedno cnote fthraćić A w niecznocie iuż ze wfzem złym wiecżnie fie pobrácić (SXVI). Stąd też pewnie wynika pouczający ton widoczny w części zapisów omawiających cnotę kobiety, jak np. u Kochanowskiego: Náwet áni głádkości ták wam fzukáć trzebá / Iáko wftydu / á cnoty / darów przednich z niebá, / Bo ácz to wjzytko dobré / y ma /we przyfmaki / Ale z cnota złożywfzy póydzie między bráki (SKoch).

Była już mowa o stawianym kobiecie wymogu umiłowania cnoty, o jego doniosłości może świadczyć powtórzenie w kolejnym zapisie: Owa miłość cznoty / toć to ieft naytwárdfzy munfztuk / białymgłowam (SXVI). Nieprzypadkowe chyba jest tu użycie, chciałoby się rzec, „końskiej” przenośni „najtwardszy munsztuk” (munsztuk 'wędzidło, przyrząd do kierowania i hamowania koni' SXVI), sugerującej narzucanie pewnych wartości i zachowań $\mathrm{z}$ jednej strony i wyznaczającej miejsce w świecie $\mathrm{z}$ drugiej. Dodatkowego znaczenia nabiera ona $\mathrm{w}$ zestawieniu z późniejszym (a może tylko później odnotowanym) przysłowiem: Konia i niewiasty trudno dostać ze wszystkimi cnotami (SWil), świadcząc ponuro o traktowaniu kobiety jako części inwentarza w patriarchalnym społeczeństwie ubiegłych wieków.

Kobieta jest przedmiotem umów małżeńskich, w których warunkiem jest zachowane dziewictwo, co pokazuje zapis: Pufzcżaiąc $w \int \tan M a ł \dot{e} e n ́ f k i / \int w o i e$ śiestrzenicę W cnotách nie náwątloną: iák w oku źrzenicę (SXVI). Porównanie do źrenicy oka przywołuje wartość najwyższą, najcenniejszą i odpowiednio strzeżoną, a określenie „w cnotach nie nawątloną” pokazuje, na czym ona polega. Nawatlony w SXVI to 'osłabiony, wyczerpany, pozbawiony dotychczasowego znaczenia' - zatem pozbawienie dziewictwa oznacza utratę znaczenia. Daje się jednak w tym kontekście wyczuć zachwalanie siostrzenicy, jako towaru pierwszej klasy, z zaakcentowaniem jedynej cechy, z której ta wartość wynika.

Cnota w rozumieniu 'dziewictwo' jest w zasadzie jedynym wyznacznikiem wartości kobiety, na dodatek w hierarchii wartości przewyższa jej życie. Innymi słowy - kobieta pozbawiona cnoty tak pojmowanej traci prawo nie tylko do życia w społeczeństwie, co było widoczne w poprzednich kontekstach, traci prawo do życia w ogóle. Śmierć z powodu utraty cnoty lub w jej obronie jest opisywana dość często: Hetman [...] chciat ia zá żonę mieć / Oná niż 
cnotę zruszyć / wolátá fie zábić (SXVI); Ale wolę bez winnośći od wáfzych rąk zginać / Niż przed Bogyem / y przed ludźmi niecnotliwa Jtynąć (SXVI). Fraza „niecnotliwą słynąć” wydaje się uzasadniać wybór śmierci z punktu widzenia kobiet, które przecież zdawały sobie sprawę z wykluczenia ze społeczeństwa i skazania na margines i życie w nędzy w wypadku utraty cnoty czy okrzyknięcia niecnotliwą. Wybór ten był oczywiście narzucony realiami społecznymi, ustalanymi przez mężczyzn, co wprost wyraża zapis: Wole iż $w$ piekle żyiejz cnotliwa ná wieki / A niż majz żyć na fwiecie tu w wielkiey fromocie / Nie chcę ia ciebie widzyeć tu $w$ tákiey niecnocie (SXVI). Istotne jest, że autor tych słów stawia cnotę swojej żony wyżej niż jej wieczne zbawienie. Zastanawiający jest też stosunek do samobójstwa - jest ono w kulturze chrześcijańskiej potępiane jako grzech, w tym jednak przypadku, gdy chodzi o wybór śmierci z własnej ręki dla obrony cnoty, nie da się w kontekstach zauważyć żadnej negatywnej oceny. Czyżby znaczyło to, że szesnastowieczne patriarchalne społeczeństwo ten wybór popierało? Wydaje się, że tak, ponieważ zapisy sprawiają wrażenie prezentacji kobiecych wzorców osobowych. Niewątpliwym ideałem kobiety jest Lukrecja: [Lukrecja] zábiłá fie fámá mowyąc / nyechcę wyęcey żyć ná fwyecye / gdy mi moye cnotę wyrwano (SXVI), tym bardziej tragicznym, iż była ofiarą gwałtu, a wybierając samobójczą śmierć, stała się ofiarą podwójnąa . Na szczęście, nie były te wymogi tak radykalnie egzekwowane w codziennym życiu, ponieważ znane są przypadki, w których kobieta nie ponosiła aż tak ciężkich konsekwencji utraty cnoty, nawet, gdy owocowała ona nieślubnym dzieckiem. M. Bogucka $(1998,38)$ przytacza przykład z połowy XVII w., kiedy Katarzyna Sobieska, siostra późniejszego Jana III, urodziła nieślubne dziecko krótko po zawarciu przymusowego małżeństwa z księciem Zasławskim-Ostrogskim, który „okazał się tolerancyjny”, chociaż cała sprawa odbyła się w atmosferze głośnego skandalu.

Zachowana kobieca cnota bywa przedmiotem pochwały, niekiedy odczuwalnej tylko w tonie wypowiedzi: Mnogie Pánie iż from maia / W daw-

${ }^{9}$ Lukrecję, żonę Tarkwiniusza Kollatinusa, podstępnie zgwałcił syn Tarkwiniusza Pysznego - Sextus. Późniejsza tradycja powiązała z tym wydarzeniem bunt przeciw Tarkwiniuszom i ich wygnanie. Powstanie pod wodzą Brutusa doprowadziło ok. 510 r. p.n.e. do obalenia monarchii i powołania republiki (Krawczuk, 1992, 47-51). Życie Lukrecji stało się tematem wielu dzieł literackich, muzycznych, malarskich różnych epok, np. Sachsa, Szekspira, Arnauta, Giraudoux, Händla, Brittena, Boticellego, Tycjana, Tintoretto, Rubensa, Rembrandta. W XVI-wiecznej Polsce stało się inspiracją dla Reja i Kochanowskiego. Współcześnie rozumiana historia Lukrecji stanowi dowód na to, iż gwałt pozostawia w psychice kobiety trwały uraz, który może prowadzić do najtragiczniejszego rozwiązania, jednak przedstawianie jej wyboru w kategorii ideału jest dziś niewyobrażalne. 
ney cnoćie łatwie trwáia (SXVI), a niekiedy nazwanym wprost powodem do oddawania czci i wysławiania: [...] á ifz tym iey cnoty pánieńfkie czyftość y świątobliwość vcżcić y wsławić chciał (SXVI). Kolejny kontekst przedstawia sytuację, w której kobiety zachowują cnotę nawet mimo małżeństwa: iefli fie to trafia miedzy inemi białemigłowámi / że poniewoli drugie zá Jtáre / zá chore / zá vłomne małżonki fzedfzy / cnote /wa wcále záchowuia (SXVI). Nie daje się tu wyczuć żadne nacechowanie, raczej jest to stwierdzenie faktu, niemniej przedstawia przerażający obraz kobiecego zniewolenia.

W jednym kontekście wspomniano o tym, że obowiązkiem człowieka rycerskiego jest obrona kobiecej cnoty: káżdy rycer/ki cżłowiek winien o prawdę ręka cżynić [...] á nie dopuścić / áby czna białagłowá niewinnie poháńbiona zoftáłá (SXVI). To jedyny zapis zobowiązujący także mężczyzn do odpowiedzialności za cnotę kobiet, nad którymi sprawują opiekę, a może nawet wszystkich kobiet.

Pokazywanie cnoty jako wartości najwyższej pośród cech kobiety, często łączy się z urodą. W zestawieniach takich uroda uznawana jest za zaletę kobiety, jednak niewystarczającą, stanowiącą często jedynie tło do pokazania prawdziwej wartości, stawianej zawsze ponad inne, jak u Kochanowskiego: Perły / á złoto ... Vbiór téy zacnéy pánny / [...] Ale przy twarzy gáfnie vbiór złoty / A záś vrodę przeważáia cnoty (SKoch). Dalsze zapisy dotyczą zapewne również urody kobiecej, bo dla mężczyzny nie jest ona walorem o tak istotnej wadze ${ }^{10}$ : Wfzák máło po vrodzye kiedy nie máfz cnoty (SXVI); Słába vrodá bez cnoty (SXVI). Określenie „mało po urodzie” odnosi się chyba do praktycznego aspektu korzyści z różnego rodzaju zalet kobiety, widzianej jako potencjalna żona. Podobny punkt widzenia jest wyrażony w kolejnych cytatach: Dobrzeć fnadź głádka poyąć / ále ktoraby y cnotę myáta (SXVI); nyech fie nye kwápi ná byáła głowę / ktoraby płćia álbo brwyámy dobrze ftáła ale coby byłá cnotliwa / státecżna / á v ludzi w dobrem mnimányu $(\mathrm{SXVI})^{11}$. Takie połączenie urody $\mathrm{z}$ cnotą kobiety - walorów zewnętrznych

${ }^{10}$ Staropolski kontekst: Mila bracza, powiadaam waam zaprawdø, yzee vrøpnoscz czyny czøsto z møsczyny nyewieesczee serczee (Sstp) 'Miła bracia, powiadam wam zaprawdę, że urępność czyni często z mężczyzny niewieście serce’ nie tylko to potwierdza, ale i sugeruje, że męska urępność jest zjawiskiem niebezpiecznym i niepożądanym. Zapis jest tym ciekawszy, że użyto w nim całkowicie dziś zapomnianego leksemu urępność 'uroda, piękna powierzchowność' (Sstp, por. urępny, urupny 'piękny, urodziwy' Sstp).

${ }^{11}$ Płeć, wg SXVI także 'powierzchnia ciała ludzkiego, skóra (przede wszystkim twarzy) oraz jej wygląd, kolor, cera itp., brew 'ts.', 'powieka' (SXVI) - jedno i drugie miało zapewne istotne znaczenie przy ocenie urody kobiecej, stanowiąc ważne czynniki składające się na ustalony kanon piękna. 
$\mathrm{z}$ wewnętrznymi wystąpiło już w staropolszczyźnie: Kraszna yesz panna ve cznosczy (Sstp).

Do wzorca żony w społeczeństwie szesnastowiecznym nawiązuje prawdopodobnie połączenie cnoty (w znaczeniu 'czystość seksualna') kobiecej ze wstydem i pokorą: Ktemu theż thego chczę / áby káżdy poftępek iey / byt s pokora / á ze w/tydem złaczony / bo the cnocie / białagłowe zbytnie zdobia (SXVI). Pokora, wg SXVI 'poczucie własnej niższości, małego znaczenia, uległość, uniżoność, skromność ${ }^{\prime 2}$, zapewne widziana była jako zaleta kobiety w patriarchalnym społeczeństwie w sensie ogólnym, ale praktycznie musiała odnosić się szczególnie do męża, ojca czy brata, a więc mężczyzny sprawującego władzę nad kobietą, wobec którego winna mieć poczucie niższości i być uległa. Te właśnie cechy zawierają się w często wspominanym wzorcu cnej czy cnotliwej żony: Ale y on żony pierwey / Tákież powiádat cnoty iey: Iż byłá cna y pokorna (SXVI); Godno płáczu niefczęście [...] Bos pozbył towárzyfzá y cnotliwéy żony / Któréy dobroć / któréy w/tyd ieft nie wyftowiony (SKoch). O wysokim uznaniu dla ideału cnej żony świadczy nazwanie jej klejnotem: Zona cnotliwa ofobny klenoth (-) Mam też żonkę podćiwa wftydliwa powolng Ni w czym mi nie przekaża (SXVI), zawierające równocześnie, poprzez użycie przymiotnika osobny ('wyjątkowy, inny niż wszyscy, dziwny, zwracający uwagę, szczególnie dobry' SXVI) aluzję, że pożądane przez mężczyzn wzorcowe cechy żon stanowią rzadkość. Niekiedy w takim wyobrażeniu żony zawiera się także jej uroda: Dáley oto będzie miat dzieweczkę cnotliwą, Pokorna, vrodziwa (SXVI). Natomiast w kolejnym zapisie widać niejako oczekiwanie, być może $\mathrm{w}$ imię wymaganej pokory i wstydliwości, aby kobieta nie przyznawała się do własnej urody, aby się od niej odżegnywała i uważała ją za krępującą: Iáko ieden chwalac białagłowę / $z$ obycżajow / $z$ dobroći / s cnoty / nákoniec y s cudnośći / kiedy oná tey ofthátniey chwały nie prziymuiąc / rzekłá ... (SXVI). Opierało się ono pewnie na przekonaniu, że uroda nie sprzyja zachowa-

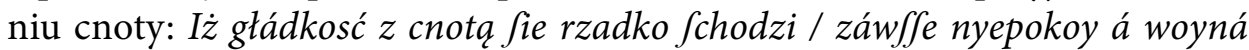
(SXVI). Takie rozumowanie mogło wiązać się z utrwalonymi w kulturze postaciami pięknych kobiet, jak np. Heleny Trojańskiej, o której pisano: By tylko tá nas nie miáłá Ziemiá / z ktoréy przyiecháłá / Oná nie Jzpetnégo licá / Ale jprofna bezecnicá (SXVI). Wydaje się, że uroda skojarzona jest w przypadku tej antycznej bohaterki z najgorszymi dla kobiety zarzutami, wyrażonymi określeniem „sprośna bezecnica”. Bezecnica w XVI w. to 'kobieta bez czci, bez honoru, występna, rozpustnica' (SXVI) - w definicji zawarte jest odniesienie do sfery seksualnej, a samo określenie jest mocno nacechowane negatywnie.

12 O pojęciu pokora por. Grz e g or c zykowa 1993, 23-39. 
Znaczenie przymiotnika sprośny 'tani, bez wartości, lichy, marny', 'niecny, niegodziwy, nikczemny' (Sstp) potwierdza z jednej strony odmawianie jakiejkolwiek wartości kobiecie rozpustnej, niezachowującej czystości, z drugiej wzmacnia negatywny ładunek emocjonalny.

Wydaje się, że specyficzne rozumienie pojęcia cnota w odniesieniu do kobiet, odmienne od cnoty dotyczącej mężczyzn, było ustalone już w XVI w. Ważne miejsce w nim zajmuje czystość seksualna. Występuje ona w znaczeniu chyba szerszym niż współczesne dziewictwo, można sądzić, że rozciąga się na całą sferę seksualności kobiety, stawiając jej wymóg nie tylko zachowania cnoty do zamążpójścia, ale też ograniczenia sfery seksualnej do kontaktów wyłącznie małżeńskich ${ }^{13}$, a także zachowywania skromności i wstydliwości w kontaktach towarzyskich. W szesnastowiecznym obrazie cnoty kobiety widać pewną dwoistość - jest ona wartością z jednej strony czczoną, wysławianą, $\mathrm{z}$ drugiej egzekwowaną od kobiet w sposób bezwzględny, pod rygorem śmierci nie tylko społecznej, ale i biologicznej. Jakkolwiek cnota pochwalana jest przez mężczyzn, to jednak kobieta jest obarczona odpowiedzialnością za jej zachowanie i obronę, ona jest piętnowana, jeśli cnoty nie uchroni. Mężczyzn, którzy na cnotę nastają, potępia się wprawdzie, ale nie tak radykalnie ${ }^{14}$.

Dostępny materiał słownikowy z kolejnych wieków ${ }^{15}$ przynosi dalsze ślady innego rozumienia cnoty $\mathrm{w}$ zależności od płci. Jednak nie są one już tak bogate, jak w XVI w., co wynika naturalnie z charakteru źródeł. Słownik

${ }^{13}$ Bardzo silnie akcentowane obyczajowe skrępowanie kobiet mogło mieć szczególne znaczenie w świetle częstych i długotrwałych nieobecności mężów, wyjeżdżających na sejmiki i wojny, do tego zapewne odnosi się cytat: Zono miła poyde ia do ziemie fwietey / á przetoż profzę ćie ábyś thu cnotliwie żyłá wedle przykazania bożego (SXVI). Zwraca w nim uwagę ton łagodnej prośby i zwrot „Żono miła” - świadczą one jednak o szacunku i pewnym przywiązaniu współmałżonka, odmiennie od manifestacji tyranii widocznej w cytowanym wcześniej zapisie, w którym mężczyzna woli widzieć kobietę w piekle niż w niecnocie.

${ }^{14}$ Świadczy o tym np. kara za gwałt na chłopce obowiązująca w średniowieczu: „Kara była jeszcze mniejsza, jeśli zgwałcona córka chłopa znalazła się sama w lesie lub polu, "gdzie jej nie kazano chodzić«. Wówczas winny płacił tylko drobną karę, zwaną "trzysta«" (B a r da ch, Leśn od or ski, Pi et r zak 1998, 155). W karze tej, pochodzącej z Najstarszego zwodu prawa polskiego, tzw. Księgi elbląskiej, zwraca uwagę przeniesienie odpowiedzialności z przestępcy na ofiarę - w określeniu "gdzie jej nie kazano chodzić” de facto zawarte jest stwierdzenie, że sama ponosi winę.

${ }^{15}$ Słownik Lindego cytuje niewiele zapisów wiążących cnotę z kobietą. Dostępny w internecie materiał z przygotowywanego Słownika języka polskiego XVII i 1. poł. XVIII w. w ogóle takich połączeń nie zawiera, ale hasła cnota, cnotliwy, cny, niecnota, niecnotliwy są dopiero w opracowaniu. U Paska (SPas) pod cnota, cnotliwy, cny, niecnota, niecnotliwy nie ma odniesienia do kobiety w ogóle, jest tylko aspekt rycersko-patriotyczny, wszystkie zapisy dotyczą wojen, co w XVII wieku nietrudno zrozumieć. 
polszczyzny XVI w. podaje bardzo bogatą dokumentację, późniejsze słowniki prezentują materiał znacznie skromniej.

U Lindego znajdujemy wyodrębnione określenie cnota niewieścia z objaśnieniem 'wstyd'. Na podstawie wcześniejszych połączeń cnoty, wstydu i czystości można uważać, że wstyd odnosi się tutaj do sfery seksualnej i szerzej, do kontaktów męsko-damskich, w których kobieta wstyd i cnotę zachować powinna. Szereg Cnota i niewinność (L) nie ogranicza się na pewno do erotycznych aspektów życia, ale leksem niewinność może sugerować, że i tu cnota łączy się z dziewictwem i ma związek z kobietą ${ }^{16}$. Cnota kobiety znajduje się w niebezpieczeństwie, jak czytamy w zapisie: Dworzanie na cnotę białychgłów czuwaja $^{17}$ (L). Utrata cnoty jest przedmiotem kpiny, ironii: Cnota jej, aż sie za niq wlecze, jak u sukni ogon (zaszargała się) (L). Kluczowe wydaje się tu doprecyzowanie w nawiasie - zaszargać się, szargać się u Lindego znaczy 'błotem zanieczyścić, przenośnie odnosi się do niweczenia wartości, co pokazuje kontekst: On $z$ moja powaga, wasza razem szarga; Na nasze przywileje, na władzę się targa (L). Zatem widać negatywną ocenę takiego zachowania, ale żaden zapis nie przedstawia tak radykalnego potępiania tego zjawiska, jak to miało miejsce w XVI w., kiedy żądano, by kobieta za cnotę oddawała życie. W siedemnastowiecznym Liber Chamorum Nekandy-Trepki znajdujemy poświadczenia ceny, jaką kobieta płaci za utratę cnoty: Dtugo będac u niego pojąt był Piaskowska niejaka; miała „ale”, jak mówia, w cnocie, nie pojałby jej byt, tylko chłopski syn (cyt. za Mońko-Chotkowska 1977, 189); dadza-ć i chłopu szlachciankę, kiedy „ale” do której jest (cyt. za Wiśniewska 2003, 237) - jest nią dla szlachcianki konieczność zamążpójścia za chłopskiego syna, czyli zejścia do niższej grupy społecznej, więc mamy do czynienia ze społecznym wykluczeniem, ale już nie z odmówieniem prawa do życia. Wymienione tu „»ale« w cnocie” oznacza najprawdopodobniej brak dziewictwa, jednak trzeba zastrzec, że taki odbiór może wynikać ze współczesnego kojarzenia cnoty z dziewictwem, w 1. poł. XVII w. mogło odnosić się do szerzej ujmowanych negatywnych $\operatorname{cech}^{18}$. Jednak założenie, że cnota kobieca zazwyczaj wiąże się ze sferą seksualną, jest chyba uprawnione. Uzasadniają je te $\mathrm{z}$ wcześniejszych kontekstów, w których takie rozumienie jest bezsporne, a potwierdza zapis: Niecnotnica, która męża mego uwiodła (L), gdzie niecnota oznacza uwodze-

${ }^{16}$ U Lindego niewinność nie łączy się jednoznacznie z aspektem seksualnym, objaśnienie przymiotnika niewinny brzmi 'bez najmniejszej skazy, niepokalany' (L), ale w Słowniku wileńskim znajduje się zapis: Jeszcze jest $w$ stanie niewinności (SWil), co przywołuje sferę seksualną.

${ }^{17}$ Czuwać na co 'czyhać, czuhać na co, czatować' (L).

${ }^{18} \mathrm{H}$. Wiśn niewska $(2003,236)$ umieszcza ten zapis w rozdziale Nierządnice i metresy, wiążąc tym samym „ale” w cnocie z uprawianiem nierządu, a zatem ze sferą seksualną. 
nie, czyli działania w sferze erotycznej. Warto zauważyć, że oskarżycielką jest tu kobieta, która piętnuje „niecnotliwe” zachowanie innej kobiety, a nie współwinnego w końcu w równej części mężczyzny. Taki mechanizm, jak wiadomo na podstawie zwykłej obserwacji codzienności, funkcjonuje do dziś i wynika zapewne nie tylko $\mathrm{z}$ emocji, ale też $\mathrm{z}$ bardzo silnie zakorzenionego w społeczeństwach patriarchalnych zwyczaju obarczania odpowiedzialnością za naruszenia ładu moralnego kobiet, a nie mężczyzn. Podobny wydźwięk ma zapis: Staneła y ona bezecnica niewstydliwa namowiona przed urzędem nárzekáiac o gwałt sobie uczyniony (SXVIIkart: WisCzar52). Nie rozstrzyga on jednoznacznie, czy określenie „bezecnica niewstydliwa” dotyczy sfery seksualnej, co wydaje się prawdopodobne, gdyż sprawa dotyczy zarzutu cudzołóstwa, przedstawionego przez kobietę jako gwałt (gwałt na ciele, nie na mieniu), czego oskarżany sprawca się wyparł, zarzucając ofierze kłamstwo ${ }^{19}$.

W Słowniku wileńskim cnotliwa kobieta, niewiasta to 'strzegąca wstydu, czystości, zachowująca niewieścią cnotę' (SWil). Znaczenie przymiotnika cnotliwy w stosunku do kobiety wydaje się odnosić do sfery seksualnej. W zapisie: Miło tam patrzéć, gdzie w nadobném ciele, cnota z rozumem gniazdo sobie ściele (SWil) wyrażono pewien ideał kobiety - pięknej, rozumnej i cnotliwej. Ten kontekst nie przekonuje, że cnota ogranicza się do znaczenia 'dziewictwo'.

Słownik warszawski w definicji ogólnej cnoty podaje też wyrażenie cnota niewieścia z objaśnieniem 'wstydliwość, skromność. Nie zaznaczono tu konkretnego odwołania do dziewictwa. Wstydliwość odnosi się raczej do pewnego wzorca zachowań kobiet w towarzystwie. Jednak cytowane przysłowie: Cnota pilnowana djabła warta (SW) - wydaje się odnosić do czystości seksualnej - „pilnowana cnota” ma chyba wąskie znaczenie 'dziewictwo', zaznacza się tu zresztą dawno już znany wymóg umiłowania cnoty przez kobietę, wykluczający konieczność pilnowania niejako z zewnątrz. Nie podano w słowniku, z jakiego okresu pochodzi przysłowie, ale inne słowniki go nie przytaczają. Zamieszczone w SW wyrażenie cnota dziewicza 'niewinność, czystość, niepokalaność, wianek' jest zawężeniem znaczenia tylko do sfery seksualnej, nie jest, niestety, opatrzone żadnym cytatem.

We współczesnym słowniku Doroszewskiego definicja cnoty jako pojęcia ogólnego nie różni się zasadniczo od tej w dawniejszej polszczyźnie. Warto

${ }^{19}$ Kontekst przywołany w słowniku jest zbyt krótki, dlatego korzystałam z całego dokumentu, który zresztą nie rozstrzyga jednoznacznie wątpliwości. Jest to znajdujący się w Bibliotece Jagiellońskiej manuskrypt z 1639 r., dostępny w formie mikrofiszek o sygnaturze MF 005872 (odpowiedni fragment znajduje się na s. 48-49), egzemplarz inny niż źródło SXVIIkart. 
jednak zwrócić uwagę, że w poświadczeniach źródłowych, przeważnie starszych niż XIX wiek, cnota występuje często w kontekstach historycznych, $\mathrm{z}$ określeniami tradycyjna czy legendarna. Wskazuje to, że w XIX w. cnota - 'zespół dodatnich cech moralnych' jest już pojęciem rzadko używanym, nieco archaicznym. Nie dotyczy to jednak cnoty w znaczeniu 'dziewiczość, niewinność, czystość, ta udokumentowana jest w słowniku dobrze, $\mathrm{w}$ większości zapisami z XIX i XX w. Tradycyjnie utrzymana jest wyraźna zależność między wartością kobiety a jej dziewictwem, które warunkuje szanse na zamążpójście, a co za tym idzie, pozycję społeczną kobiety: Stara Klimecka zaprzysięgała, że nie da sie żenić synowi $z$ dziewucha, co już nie $z$ jednym swoja cnotę traciła (SJPDor). Nadal cnota kobieca jest postrzegana jako wartość w stanie zagrożenia, na którą stale ktoś czyha i próbuje upolować: Urwipołeć taki, koszuli na grzbiecie nie majacy [...] sidła tylko na cnote głupiej dziewczyny zastawia (SJPDor); Nie dybie wcale na cnote panny Wandy (SJPDor); Panna jak malowana, nie dziwota zatem, iż wielu kawalerów już na jej cnote dybało (PWSP). Skoro jest zagrożenie, pojawia się i obrona, a przy niej widoczne usytuowanie kobiecej cnoty wysoko w hierarchii wartości: Broniła swojego grosiwa, jak żadna dziewczyna mężniej swojej cnoty bronić nie może (SJPDor). Obrona zresztą tradycyjnie nie jest wyłącznie sprawą samej zainteresowanej, ale i jej otoczenia: Pannę Aniele na kilka tygodni do Warszawy wysłano, gdzie ciotki Pomianowskie nad jej cnota czuwać miały (PWSP). Chociaż utrzymuje się wysokie wartościowanie cnoty kobiecej i nadal ma ona wpływ na ocenę samej kobiety, zwłaszcza jako przyszłej żony, to jednak wymagania te nie są już w XIX w. traktowane tak restrykcyjne. „Panieńska cnota” pojawia się u Fredry w kontekście żartobliwym: Chca mężczyzn zgubić; trwać $w$ panieńskiej cnocie? (SJPDor), co może świadczyć o pewnym rozluźnieniu obyczajowych rygorów.

W znaczeniu cnoty utrwala się „czystość seksualna”, podczas gdy ogólniejsze znaczenie wychodzi z użycia. Widać to w derywatach od cnoty - cnotliwość to 'szlachetność, prawość, dobroć, zacność', ale już z zastrzeżeniem 'dziś prawie wyłącznie czystość, niewinność' (SJPDor). W Słowniku Dunaja cnotliwość ma już pierwsze znaczenie 'skromność w sprawach dotyczących seksu, przyzwoitość, czystość, niewinność, a dopiero drugie jest tradycyjne - 'prawość, zacność, szlachetność' (SJPDun), taki sam układ znaczeń widnieje pod przymiotnikiem cnotliwy. Cytaty obrazujące użycie tego przymiotnika dotyczą kobiet: Była cnotliwa, nie zepsuta dziewczyna (SJPDun); Jestem cnotliwa mężatka $i$ zostanę niq do końca mych dni (SJPDor). Zestawienie „cnotliwa i nie zepsuta” wciąż podkreśla pozytywne wartościowanie takiego waloru kobiety, ale pojawia się też kontekst, w którym określenie cnotliwa 
ujęto w cudzysłów, co wydaje się podważać poważne traktowanie tej wartości: Praktyczniejsze koleżanki $z$ baletu zbierały tymczasem brylanty i szmaragdy, podczas gdy „cnotliwe” czekały na narzeczonych (SJPDor). Współcześnie, zdaniem Puzyniny, „przymiotnik cnotliwy należy do niewielu leksemów o niemal w pełni skonwencjonalizowanym znaczeniu drwiącym lub lekceważąco-pogardliwym (tzn. niekwestionującym tego, że człowiek ów charakteryzuje się jakimiś cechami dobrymi, ale dającym wyraz swojemu lekceważeniu czy też pogardzie wobec takiego rodzaju dobra)" (Puzynina 1992, 160). Wydaje się, że taki właśnie wydźwięk ma powyższy cytat, podobnie jest z rzeczownikiem cnotliwość, a w pewnym stopniu także cnota. Niekiedy występują one w kontekstach bardziej neutralnych, ale i w takich przypadkach daje się wyczuć nutka ironii, np.: Bar pełen pijanych mężczyzn to na pewno nie miejsce dla cnotliwych panienek (PWSP), albo: W towarzystwie mężczyzn Zuzanna zachowywała się dokładnie tak, jak przystało cnotliwej panience (PWSP). Egzemplifikacja cnotliwości odnosi się również do kobiety i też wydaje się mieć nieco drwiący charakter: Kobieta śliczności, cnotliwość chodzaca i w głowie ma dobrze, jeno dogryza człowiekowi coraz więcej, sekuje ... (SJPDor).

$Z$ rozluźnieniem obyczajowym łączy się zapewne traktowanie cnoty, już w znaczeniu 'dziewictwo', w sposób pobłażliwy, a nawet ironiczny czy pogardliwy (w niektórych środowiskach). Wyraża się ono leksemem cnotka. Ani on sam, ani jego ironiczne zabarwienie nie jest w polszczyźnie nowe, jednak znaczenie się zmieniło. Pojawił się w XVI w. jako zdrobnienie od cnota z odcieniem pobłażliwym lub $\mathrm{w}$ formie spersonifikowanej, już ironicznie, u Lindego cnotka to 'cnota mniemana, fałszywa, pozorna - ironicznie bądź z przytykiem’ Takie znaczenie utrzymuje się aż do współczesności, u Doroszewskiego objaśnienie brzmi: cnotka 'mniemana, rzekoma, pozorna, nieprawdziwa cnota', a po spersonifikowaniu 'o osobie cnotliwej albo udającej cnotliwą'. Jak widać, nie ma tu ograniczenia do którejkolwiek z płci, ale zapis (jedyny w tym znaczeniu) dotyczy jednak kobiety: Przysięgała, że wszyscy mężczyźni zawsze się do niej odnosili, jak do cnotki (SJPDor).

W Praktycznym słowniku współczesnej polszczyzny pojawia się zmiana znaczenia już w definicji, a ściślej jego ograniczenie tylko do osoby (już nie pojęcia), na dodatek wyłącznie do kobiety. Tutaj cnotka, nadal ironicznie nacechowana, to po pierwsze 'kobieta bardzo cnotliwa - skromna, wstydliwa - albo udająca cnotliwą' (PWSP). Konteksty wydają się świadczyć o tym, że dawny wzorzec kobiecej cnoty nie jest już w XX w. traktowany poważnie: Zaskakujące było, że to właśnie Michalina, znana w stolicy cnotka, pierwsza złożyła wizytę okrytej zła sława pani Wańskiej (PWSP); Barbara uchodziła $w$ towarzystwie za cnotkę (PWSP). Po drugie, cnotka to potoczne i ironiczne 
nazwanie dziewicy: Od kiedy Rysiek kręci się z tq cnotką, Agatą? (PWSP). $\mathrm{Z}$ tego kontekstu nie wynika żaden szacunek dla dziewictwa.

Zmiana w wartościowaniu wynika naturalnie ze zmian obyczajowych, przede wszystkim ze zmiany pozycji społecznej kobiety w XX w. Ale już wcześniej cnota łączona była $\mathrm{z}$ drobnomieszczańskim modelem życia na pokaz, gdzie była wartością pozorną, udawaną. Utrwalenie tego skojarzenia powodowało, że przestała oznaczać wartość szanowaną, czasem nawet była traktowana $\mathrm{z}$ pogardą, choć $\mathrm{w}$ takim wypadku częściej używano określenia cnotka, np. jak drobnomieszczańska cnotka (PSWP), w tym znaczeniu w cytacie z Boya-Żeleńskiego: Pawlikowski swa tajemniczą „perwersyjnościq" [...] swoim upartym drażnieniem krakowskiej cnotki działał silnie na fantazje miasta (SJPDor). Także cnota (już bez zdrobnienia) bywa przedmiotem kpiny, czy przynajmniej ironii, jak u Zapolskiej: Wychowali Żabusię $w$ świętych tradycyjnych przepisach cnoty i surowości (SJPDor).

Zmiana sytuacji kobiet w życiu społecznym dokonywała się przez wieki, powoli i stopniowo, za spektakularny moment można uznać przyznanie kobietom praw wyborczych w pierwszym dwudziestoleciu XX w. (w większości krajów europejskich). Równocześnie dokonała się rewolucja obyczajowa, dająca kobietom prawa w wielu sferach życia, wcześniej zarezerwowanych dla mężczyzn, np. prawo do niezależności finansowej, do satysfakcji zawodowej, a nawet seksualnej. Współcześnie kobiety korzystające $\mathrm{z}$ (prawie) pełnego udziału w życiu społecznym dysponują wieloma atutami, jak np. wykształcenie, kompetencje i doświadczenie zawodowe, co wpływa na ocenę cnoty jako wartości - nie jest już ona ani jedyną, ani najważniejszą zaletą decydującą o pozycji kobiety, gubi się pośród innych zalet, postrzeganych jako znacznie ważniejsze. Wyzwolenie seksualne uczyniło $\mathrm{z}$ cnoty pewnego rodzaju antywartość - świadectwo zacofania, nienadążania za modną nowoczesnością. Niekiedy cnota bywa przedmiotem kpin, a w niektórych środowiskach jest wręcz wartościowana negatywnie. Daje się to odczuć w pochodzącym z najnowszej polszczyzny określeniu cnotka niewydymka 'przesadnie cnotliwa lub świętoszkowata kobieta' (SPLP). Pewien obraz odarcia $\mathrm{z}$ wartości daje zapis ze Słownika polszczyzny potocznej, zaczerpnięty z internetu, czyli najnowszej rzeczywistości: Głupolu, nic nie zdobędziesz, będąc taka cnotką. To nic złego. Każda modelka to przechodzi na początku kariery! (SPP).

Znaczenie leksemu cnota i jego zawartość zmieniło się przez wieki. Zaskakująca na pierwszy rzut oka ewolucja - od 'zacności, szlachetności, dodatnich cech moralnych' do 'dziewictwa', a nawet 'błony dziewiczej' ma jednak pewne uzasadnienie $\mathrm{w}$ historii rozumienia tego leksemu i związanych z nim znaczeń w języku polskim. Nie polega ona na zmianie znaczenia, ale 
na ograniczeniu go z bardzo szerokiego i ogólnikowego, do wąskiego i precyzyjnego - tylko do dziewictwa. Inne znaczenia, te, które w poprzednich wiekach były mocniej eksponowane niż 'dziewictwo', przestały być używane i kojarzone $\mathrm{z}$ wyrazem cnota. Zatem istotą zmiany było wyjście $\mathrm{z}$ użycia innych znaczeń. Wynika to $\mathrm{z}$ dążenia do wyrazistości w języku. Wydaje się, że właśnie znaczenie 'dziewictwo' było najbardziej wyraziste, zwłaszcza na tle różnych innych pojęć wchodzących w zakres cnoty, często niepoddających się jednoznacznemu zdefiniowaniu (dzielność, godność, mądrość, męstwo, poczciwość, sprawiedliwość). Można chyba uznać, że dokonało się ono w XX w., bo potwierdzone są jeszcze dziewiętnastowieczne użycia cnoty w znaczeniu 'zespołu zalet etycznych' Natomiast w XX w. są one, o ile się pojawiają, już raczej elementem stylizacji, archaizacji lub celowego zabiegu nadania wypowiedzi patosu.

Sama cnota jako 'dziewictwo, czystość seksualna' jest w języku obecna od XVI w., a już w staropolszczyźnie dają się zaobserwować ślady takiego pojmowania, przy czym czystość seksualna była niejako rozszerzona na odpowiednie zachowanie kobiety w sferze seksualnej, a nawet towarzyskiej przez całe życie. To znaczenie, początkowo funkcjonujące jako jedno $\mathrm{z}$ wielu, widoczne jest przez cały badany okres. W XVI w. cnota kobiety w takim rozumieniu jest traktowana bardzo radykalnie i umieszczona wysoko w hierarchii kobiecych przymiotów. W późniejszych wiekach nie traci na wartości, ale jest mniej kategorycznie wymagana. Łączy się to ze zmianą miejsca i roli kobiety w społeczeństwie, która przebiega wprawdzie bardzo powoli, ale konsekwentnie. Zjawiska te znajdują odbicie w językowym obrazie cnoty kobiecej, która coraz bardziej ogranicza się do sfery stricte seksualnej, gdyż wymogi skromnego zachowania kobiety $\mathrm{w}$ kontaktach towarzyskich ulegają złagodzeniu wraz z rozwojem kultury i nabywania przez kobiety wolności. Cnota stopniowo przestaje być wartością najważniejszą, a niedawno, w najbliższej nam współczesności w języku potocznym właściwie w ogóle przestaje oznaczać wartość. Ale najpierw następuje utrata tradycyjnego znaczenia, ograniczenie do samego dziewictwa, a potem, w związku ze zjawiskami pozajęzykowymi, jak rozluźnienie obyczajowości w sferze seksualnej - utrata wartości. W języku potocznym następuje dalej przejście od abstractum do concretum 'błona dziewicza'. Jasne określenie tego w słownikowej definicji jest wyrazem odtabuizowania nazw związanych z organami płciowymi. Niemniej, określenie cnota w rozumieniu 'błona dziewicza' jest przecież eufemizmem, a znana od XVI w. fraza stracić cnotę w odniesieniu do kobiety prawdopodobnie wyraża to samo znaczenie - objęty przez wieki językowym tabu akt seksualny, z negatywnym wartościowaniem konotowanym przez czasownik stracić. 


\section{Literatura}

Bardach J., Leśnodorski B., Pietrzak M., 1998, Historia ustroju i prawa polskiego, Warszawa.

B o g u cka M., 1998, Białogłowa $w$ dawnej Polsce, Warszawa.

B og u cka M., 2005, Gorsza płeć. Kobieta w dziejach Europy od antyku po wiek XXI, Warszawa.

Grzegorczykowa R., 1993, POKORA, PYCHA i pojęcia pokrewne, [w:] Nazwy wartości. Studia leksykalno-semantyczne, red. J. Bartmiński i M. Mazurkiewicz-Brzozow ska, Lublin, 23-39.

Ję drzejko E., 2000, O językowych wykładnikach pojęcia wstyd i różnych koncepcjach opisu, [w:] „Język a kultura”, t. 14: Uczucia w języku i tekście, red. I. Nowakowska-Ke m pna, A. Dąbrowska, J. A nusiewicz, s. 59-77.

Krawczuk A., 1992, Rzymianki, Warszawa-Kraków.

Lé o n - D u fou r X., SJ (red.), 1985, Słownik teologii biblijnej, Poznań - Warszawa.

Mońko-Chotkowska J., 1977, Budowa słowotwórcza rzeczowników w Liber chamorum Waleriana Nekandy-Trepki, Wrocław - Warszawa-Kraków-Gdańsk.

Puzynin a J., 1992, Język wartości, Warszawa.

Ras zewska-Żu rek B., 2006, Kształtowanie się nazwisk równych imionom w Polsce (wiek XIII-XVI), Warszawa.

Tatarkiewicz W., (1931; 1978 - wyd. 8), Historia filozofii, t. I: Filozofia starożytna i średniowieczna, Warszawa.

Wiśn i e w ska H., Świat płci żeńskiej baroku zaklęty w słowach, Lublin 2003.

\section{Wykaz źródeł}

L - Lin de S. B., Słownik języka polskiego, t. I-VI, Lwów 1854-1860.

PWSP - Praktyczny słownik współczesnej polszczyzny, red. H. Zgółkowa, t. I-L, Poznań 1994-2005.

SXVI - Słownik polszczyzny XVI wieku, red. M.R. Ma y e now a, F. Pe płow ski, t. I-XXXIV, Wrocław - Warszawa - Kraków 1966-2010.

SXVIIkart - Słownik języka polskiego XVII i XVIII w. - przygotowywany przez Instytut Języka

Polskiego PAN - kartoteka dostępna jest na stronie internetowej http://sxvii.pl

SJPDor - Słownik języka polskiego, red. W. D or o s z e w s k i, t. I-XI, Warszawa 1958-67.

SJPDun - Słownik współczesnego języka polskiego, red. B. D u n a j, Warszawa 1966.

SJPSzym - Słownik języka polskiego, red. M. S z y m c z a k, t. I-III, Warszawa 1978-81.

SKoch - Słownik polszczyzny Jana Kochanowskiego, red. M. Ku cała, t. III, Kraków 2003.

SMick - Słownik języka Adama Mickiewicza, red. K. G ór s ki, S. H r a b e c, t. I-XI, WrocławWarszawa - Kraków - Gdańsk 1962-1983.

SPas - Słownik języka Jana Chryzostoma Paska, red. H. Ko n e c z n a, t. II, Wrocław - Warszawa-Kraków 1973.

SPLP - Lu b á W., Słownik polskich leksemów potocznych, t. I-V, Kraków 2001-2009.

SPP - Czeszew ski M., Słownik polszczyzny potocznej, Warszawa 2008. 
Sstp - Słownik staropolski, red. S. U r b a ń c zyk, t. I-XI, Wrocław 1953-2002.

SW - Słownik języka polskiego, red. J. Karłowicz, A. Kryński, W. Niedźwiedzki,

t. I-VIII, Warszawa 1900-1927.

SWil - Słownik języka polskiego, red. M. Olgerbra nd t, t. I-II, Wilno 1861.

WisCzar - Wisner D., Czarownica powołana..., Poznań 1680.

\section{Feminine virtue. An attempt at understanding the evolution of the meaning of cnota (virtue) over the centuries}

\section{(Summary)}

The article is devoted to the evolution of the meaning of the Polish lexeme cnota (virtue) starting from the Old Polish to the present time. The starting point is the change in the meaning of the lexeme virtue from the 'complex of ethical qualities' in the Old Polish language to the 'hymen' in the twentieth century. From the beginning of the Polish language, the lexeme virtue contained a different catalogue of values in relation to men and women. Analysis concerned these meanings which referred to a woman and were related to the valuation not only of the virtue, but also of a woman in general, taking into consideration non-linguistic, social and cultural determinants. The material comes from historical and contemporary Polish language dictionaries. The studies also included the use of lexemes related to the lexem cnota (virtue), such as an adjective cnotliwy (virtuous) or a noun cnotka (would-be virgin, goody-goody), if they concerned the woman's virtue. The meaning of the lexeme virtue in relation to a woman was associated with virginity, chastity, considered as a key factor for determining the value of a woman. Such meaning, associated with a positive valuation of virtue persisted until the nineteenth century. In the twentieth century, the broad importance of the lexeme virtue has fallen into disuse, the meaning has been narrowed to 'virginity'. Following this, in connection with social and customary changes, the virtue, already as 'virginity', lost its traditional high rating in the category of moral values. 